\title{
Transactions of the VŠB - Technical University of Ostrava, Mechanical Series
}

No. 1, 2013, vol. LIX

article No. 1945

\section{Michal ŠOFER*, Radim HALAMA ${ }^{* *}$, František FOJTÍK ${ }^{* * * *}$ \\ WEAR ASSESSMENT IN HIGH CYCLE ROLLING CONTACT FATIGUE USING SEMI- ANALYTICAL APPROACH}

\section{STANOVENÍ MÍRY OPOTŘEBENÍ V OBLASTI VYSOKOCYKLOVÉ KONTAKTNÍ ÚNAVY S VYUŽITÍM SEMIANALYTICKÉHO PŘÍSTUPU}

\begin{abstract}
Presented paper deals with ratcheting prediction in the field of contact fatigue for the case of line contact. For the stated purposes, the wear model proposed by A. Mazzu [1] is used, which stands out for its simplicity and time efficiency. The model is based on non-linear kinematic and isotropic hardening rule of Chaboche and Lemaitre. Mazzu's approach is used in order to estimate the wear of wheel specimen as well as plastic shear strain accumulation in case of rolling/sliding contact after cycles in range from $4 \cdot 10^{5}$ to $1 \cdot 10^{6}$. Obtained results are compared with experimental data, available on author's department.
\end{abstract}

\section{Abstrakt}

Předložený článek se zabývá predikcí ratchetingu $\mathrm{v}$ oblasti kontaktní únavy pro př́ípad liniového kontaktu. K daným účelům byl využit model opotřebení A. Mazzu [1], který vyniká svou jednoduchostí a s tím související výpočetní časovou efektivitou. Model je založen na nelineárním kinematickém a izotropním zpevnění autorů Chaboche a Lemaitra. Mazzuův model je využit $\mathrm{k}$ predikci opotřebení a rovněž $\mathrm{k}$ predikci evoluce plastické smykové deformace pod kontaktním povrchem pro vzorek kola v rozmezí $4 \cdot 10^{5}$ až $1 \cdot 10^{6}$ cyklů. Dosažené výsledky jsou posléze porovnány s experimentálními daty, získanými na autorově pracovišti.

\section{Keywords}

$\mathrm{RCF}$, rolling contact fatigue, wear model, Mazzu, ratcheting

\section{INTRODUCTION}

Wear and rolling contact fatigue are one of the most common damage phenomena, occurring on components subjected to cyclic loading. Despite the fact that there are available relatively powerful computer stations, we still aren't able to simulate and predict the wear process for higher number of cycles in reasonable time horizon. Therefore, the development of semi-analytical approaches is still relevant. Presented paper points to the possibility of using semi-analytical approach, developed by A. Mazzu [1], for evaluating wear rates in the field of high cycle RCF.

\footnotetext{
* Ing., Ph.D., Department of Mechanics of Material, Faculty of Mechanical Engineering, Technical University of Ostrava, 17.listopadu 15/2172, Ostrava, tel. (+420) 59732 3598, e-mail: michal.sofer@ vsb.cz

** doc. Ing., Ph.D., Department of Mechanics of Material, Faculty of Mechanical Engineering, Technical University of Ostrava, 17.listopadu 15/2172, Ostrava, tel. (+420) 59732 1288, e-mail: radim.halama@vsb.cz

**** Ing., Ph.D., Department of Mechanics of Material, Faculty of Mechanical Engineering, Technical University of Ostrava, 17.listopadu 15/2172, Ostrava, tel. (+420) 59732 3292, e-mail: frantisek.fojtik@ vsb.cz
} 


\section{WEAR ASSESSMENT WITH AIM OF MAZZU APPROACH}

Mazzu's approach [1] is based on non-linear kinematic hardening rule, introduced by Lemaitre and Chaboche [2] and is subsequently used for ratcheting prediction in case of rolling/sliding twodimensional contact. The model is based on assumption, that component $\tau_{\mathrm{xz}}$ is the only one stress component responsible for ratcheting and plastic flow in contact.

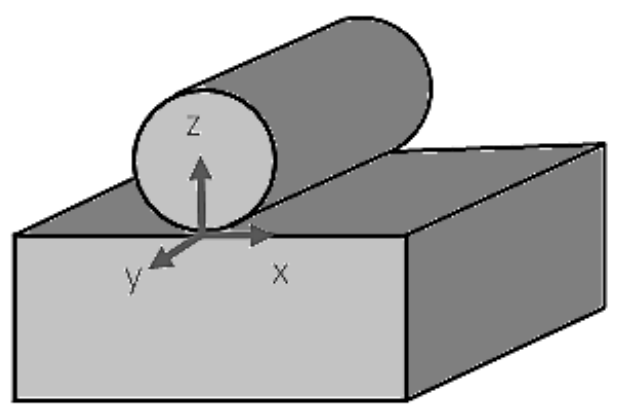

Fig. 1: Coordinate system

This hypothesis is according to [1] reasonable in case of subsurface flow where, according to Melan theorem, the kinematic hardening process is mainly affected by shear stress $\tau_{\mathrm{xz}}$, which varies within larger range compared to other deviatoric stress components whatever the friction coefficient is. In the Mazzu's model [1], elastic domain can be expressed as follows:

$$
F=\left|\sqrt{3} \cdot \tau_{x z}-X_{x z}\right|-\left(R+\sigma_{L}\right) \leq 0
$$

where:

$\sigma_{L} \quad-$ initial tensile yield stress [MPa],

$X_{x z} \quad-$ back-stress expressing kinematic hardening [MPa],

$R \quad$ - isotropic hardening [MPa]

Occurrence of plastic strain will induce variations in the isotropic and kinematic hardening terms. The back-stress variation is expressed by following equation:

$$
d X_{x z}=C \cdot \frac{d \gamma_{x z}}{\sqrt{3}}-\gamma \cdot X_{x z} \cdot\left|\frac{d \gamma_{x z}}{\sqrt{3}}\right|
$$

where:

C - material parameter [MPa],

$\gamma \quad-$ material parameter $[-]$

The isotropic term variation is given by:

$$
R=R_{\infty 1} \cdot\left[1-\exp \left(-b_{1} \cdot \frac{\gamma_{x z}}{\sqrt{3}}\right)\right]+R_{\infty 2} \cdot\left[1-\exp \left(-b_{2} \cdot \frac{\gamma_{x z}}{\sqrt{3}}\right)\right]
$$


where:

$R_{\infty 1}, R_{\infty 2} \quad$ - material parameters [MPa],

$b_{1}, b_{2} \quad-$ material parameters [-]

Generally, $R_{\infty}$ will be greater than zero if material hardens and less than zero if material softens. The isotropic term tends asymptotically to $R_{\infty}$, thereby if the plastic flow if sufficiently large, the isotropic term can be considered constant. Equation (1.2) can be analytically integrated to give:

$$
X_{x z}=v \cdot \frac{C}{\gamma}+\left(X_{x z}^{0}-v \cdot \frac{C}{\gamma}\right) \exp \left[-\frac{v \cdot \gamma}{\sqrt{3}} \cdot\left(\gamma_{x z}-\gamma_{x z}^{0}\right)\right]
$$

from where we can finally derive relation for plastic shear strain increment, where $v=1$ for loading and $v=-1$ for unloading:

$$
\Delta \gamma_{x z}=-\frac{\sqrt{3}}{v \cdot \gamma} \cdot \ln \left[\frac{X_{x z}-v \cdot(C / \gamma)}{X_{x z}^{0}-v \cdot(C / \gamma)}\right]
$$

where:

$X_{x z}^{0} \quad-$ initial value of backstress variable $[\mathrm{MPa}]$,

$\gamma_{x z}^{0} \quad$ - initial plastic shear deformation [-]

From eq. (1.1) can be obtained relation for shear stress as a function of back-stress and isotropic variable, respectively:

$$
\tau_{x z}=\frac{1}{\sqrt{3}} \cdot\left[X_{x z}+v \cdot\left(R+\sigma_{L}\right)\right]
$$

\subsection{Shear band cracking mechanism}

According to Donzella and Mazzu [3], wear is considered as an independent simultaneous phenomenon, which is progressively removing material layers from surface and influences plastic strain accumulation under the contact surface. In other words, if the critical strain $-\gamma_{\text {crit }}$ is in particular depth reached, then all material layers above will be considered as removed material. It is also worth mentioning, that Shear band cracking algorithm, as well as Mazzu algorithm have been written in C\# program language.

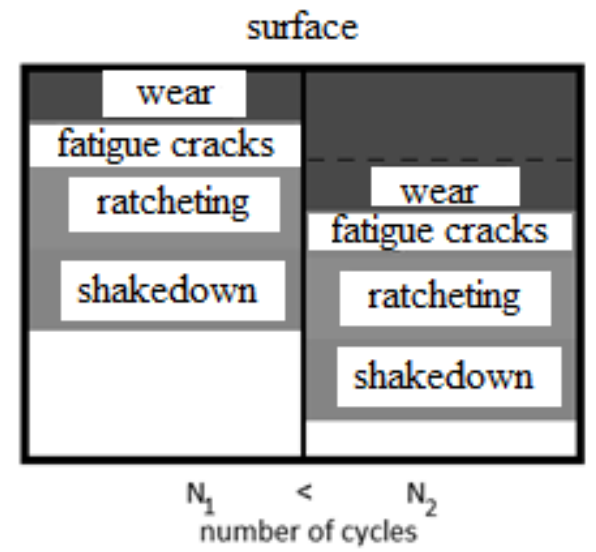

Fig. 2: Shear band cracking mechanism 


\section{PERFORMED COMPUTATIONAL STUDY}

The main aim was to evaluate the wear rates of wheel specimen (steel 11600) after 400000, 600000,800000 and 1000000 cycles under following test conditions:

- Maximum Hertz contact pressure: $p_{0}=1200[\mathrm{MPa}]$

- Hertz contact half width : $a=0.77[\mathrm{~mm}]$

- Average value of friction coefficient during entire test with slip ratio $0.75 \%: f=0,25[-]$

The identification of material parameters has been, in contrast to [3], carried out with aim of inverse algorithm [4]. Experimental data, needed for identification by itself, have to be known for cycles from 400000 to 1000000 , these data aren't however on author's department available. Therefore, according to proven linear relationship between wear rate and number of cycles [4], could we obtain reference values of wear rate with corresponding value of number of cycles with use of linear extrapolation. Following table summarizes us optimized material parameters and other parameters, needed for subsequent computational study.

Tab. 1: Parameters for wear rate evaluation

\begin{tabular}{|c|c|c|}
\hline & & Value \\
\hline \multirow{7}{*}{ Material parameters } & $C[\mathrm{MPa}]$ & 69805 \\
\hline & $\gamma[-]$ & 2,603 \\
\hline & $\sigma_{L}[\mathrm{MPa}]$ & 409 \\
\hline & $R_{\infty 1}[\mathrm{MPa}]$ & 78 \\
\hline & $b_{1}[-]$ & 0,002 \\
\hline & $R_{\infty 2}[\mathrm{MPa}]$ & 78 \\
\hline & $b_{2}[-]$ & 0,0004 \\
\hline \multirow{3}{*}{ Line contact parameters } & Maximal Hertz contact pressure $p_{0}[\mathrm{MPa}]$ & 1200 \\
\hline & Average value of traction coefficient $f[-]$ & 0,25 \\
\hline & Hertz contact half width $a[\mathrm{~mm}]$ & 0,728 \\
\hline \multirow{3}{*}{ Other parameters } & Range of inspected depths $\mathrm{z}_{\min }-z_{\max }[\mathrm{mm}]$ & $0,3-1,8$ \\
\hline & Number of layers in the range of inspected depths & 50 \\
\hline & Critical plastic shear deformation $\gamma_{\text {crit }}[-]$ & 9,1 \\
\hline
\end{tabular}

\section{RESULTS}

In graph 1 can we compare conformity between extrapolated experimental data and calculated wear rates with use of Mazzu algorithm. Used algorithm very accurately follows the linear trend in terms of relationship between wear rate and number of cycles. Also, the difference between the wear rate values from both approaches is not greater than $16 \%$ owing to extrapolated experimental data (Table 2). 


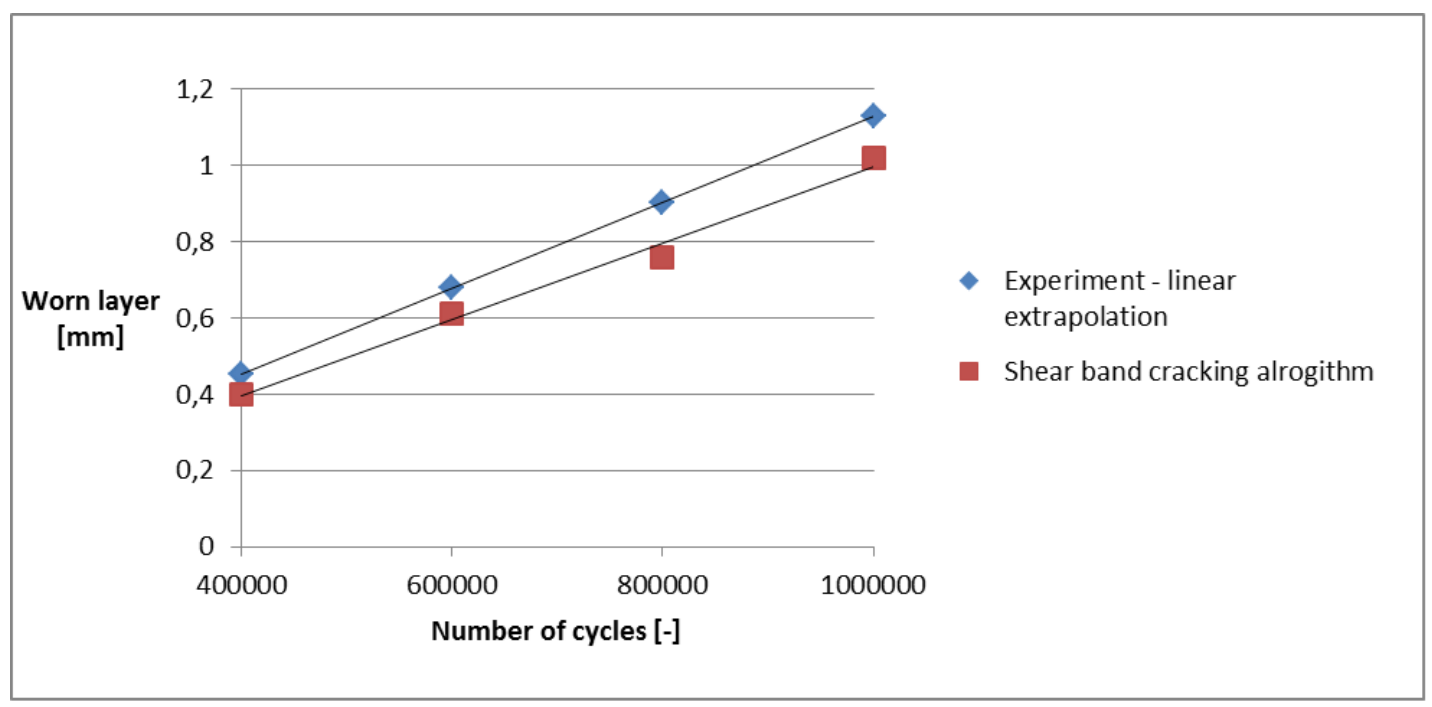

Graph 2: Parameters for wear rate evaluation

Tab 2: Radius loss for stated number of cycles

\begin{tabular}{|c|c|c|c|}
\hline \multirow{2}{*}{ Number of cycles $N[-]$} & \multicolumn{2}{|c|}{ Radius loss $h_{W}[\mathrm{~mm}]$} & \multirow{2}{*}{ Relative error [\%] } \\
\cline { 2 - 3 } & Extrapolated exp. data & Num. analysis & \\
\hline 400000 & 0,45 & 0,4 & 11,5 \\
\hline 600000 & 0,67 & 0,61 & 10 \\
\hline 800000 & 0,9 & 0,76 & 16 \\
\hline 1000000 & 1,13 & 1,02 & 10 \\
\hline
\end{tabular}

Graph 2 contains deformation profiles after 400000, 600000, 800000 and 1000000 cycles. The deformation profile tends to stabilize with increasing number of cycles, which corresponds with [3].

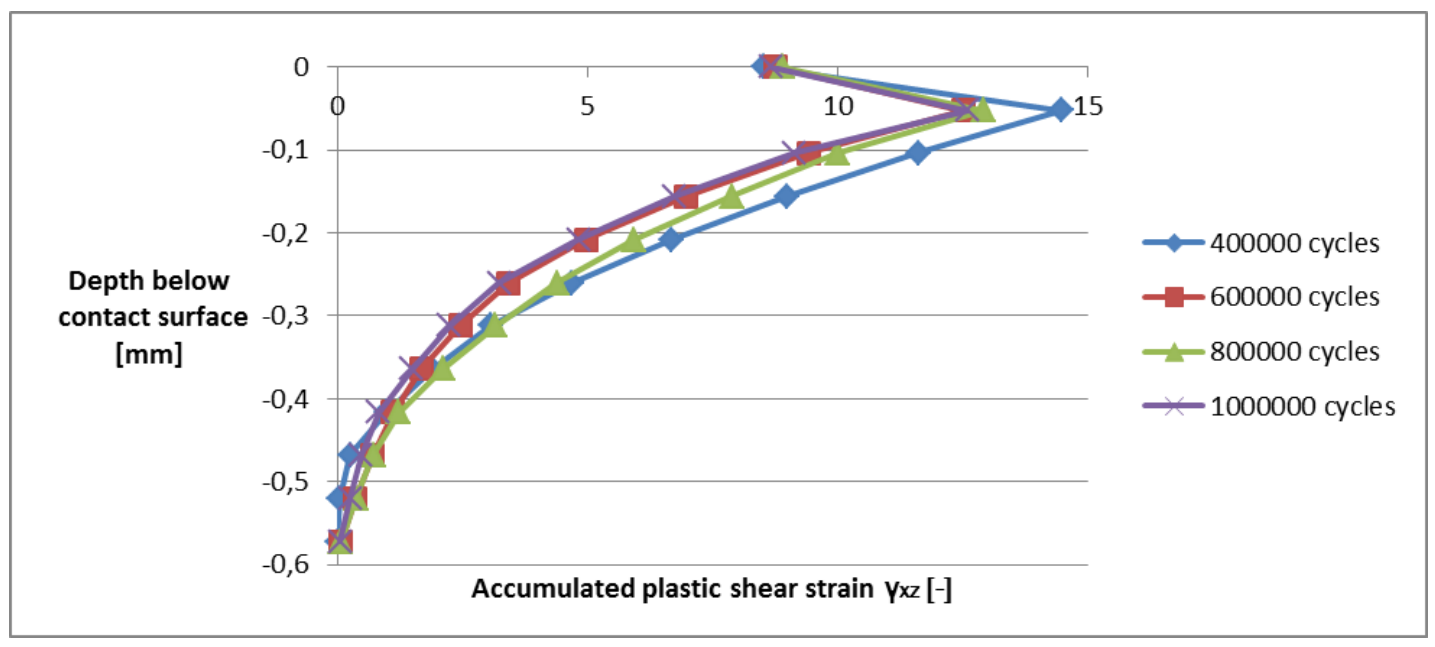

Graph 2: Evolution of deformation profile 


\section{CONCLUSIONS}

A semi-analytical approach, based on non-linear isotropic hardening model, has been used to inspect the wear rates as well as the deformation profiles under the contact surface for the case of high cycle rolling contact fatigue. The authors have developed new procedure for identification of material parameters, which was carried out with aim of inverse algorithm [4]. This approach has the advantage in time efficiency and operativeness in itself. Presented results show very good compliance with extrapolated experimental data. One of the biggest advantages of used model is the possibility of monitoring the evolution of deformation profile. As we can see, the deformation profile in our case has been stabilized after 600000 cycles which, owing to our test conditions, corresponds with [3].

\section{ACKNOWLEDGEMENT}

This paper has been elaborated in the framework of the project of specific research of Ministry of Education, Youth and Sports of the Czech Republic under No. SP2013/209.

\section{REFERENCES}

[1] MAZZU A.: A simplified non-linear kinematic hardening model for ratcheting and wear assessment in rolling contact, Journal of Strain Analysis, vol. 43, no. 5, 2008, p. 349-360.

[2] LEMAITRE, J.; CHABOCHE, J.L.: Mechanics of solid materials, 1994 (Cambridge University Press, Cambridge).

[3] DONZELlA G., FACCOLI M., MAZZU A., PETROGALLI C., ROBERTI R.: Progressive damage assessment in the near-surface layer of railway wheel-rail couple under cyclic contact, Wear, vol. 271, 2011, p. 408-416.

[4] ŠOFER, M.: Description of surface degradation of construction components due to repeated contact loading, Dissertation thesis, Faculty of mechanical engineering, VŠB-TUO, Ostrava, 2012, $126 \mathrm{~s}$. 